\title{
Principals Application of Students' Satisfaction and Leadership Principles of Total Quality Management for Secondary School Improvement in Anambra State
}

\author{
Igwegbe, Chizoba Roseline (Mrs.) \& Prof. A. S. Omenyi \\ Department of Educational Management and Policy, \\ NnamdiAzikiwe University, Awka, Anambra State Nigeria
}

\begin{abstract}
The main purpose of the study was to determine the principals' application of students' satisfaction and leadership principles of total quality management for secondary school improvement in Anambra State. Two research questions guided the study and two hypotheses were tested at 0.05 level of significance. The descriptive research design was adopted for the study. The study was carried out in Anambra State. The population of the study comprised 6664 principals and teachers (258 principals and 6406 teachers) from the 258 public secondary schools in the six education zones of the State. The sample of this study was 1999 respondents made up of 77 principals and 1922 teachers in secondary schools in Anambra State. A structured questionnaire was used to collect data. The instrument was validated by three experts in the Faculty of Education, Nnamdi Azikiwe University, Awka. The questionnaire reliability was ascertained through a pilot test. The data collected were analyzed with Cronbach Alpha and coefficient values of 0.75 and 0.77 for the two clusters with an overall reliability co-efficient value of 0.76 for the instrument. The data collected from the respondents were analyzed using descriptive statistics such as arithmetic mean and standard deviation and inferential statistics specifically the t-test. Findings revealed that principals applied students' satisfaction and leadership principles to a moderate extent. Based on the findings of the study the following recommendations were made among others, that the Post Primary School Service Commission in Conjunction with the Ministry of education should organize in-service training programmes that will educate principals on the current trends in improving students' satisfaction in secondary schools. It was also recommended that Principals should delegate responsibilities more to teachers as that will give them a feeling of belonging and increase their work commitment.
\end{abstract}

Keywords:- Principals; Application; Students; Satisfaction; Leadership Principles; School Improvement; Secondary School; Total Quality Management.

\section{INTRODUCTION}

Education is the foundation of growth and development in any society. This is because education is a tool that is used to reform the minds and intellects of its recipients. This view is further strengthened by the Federal Republic of Nigeria's (FRN, 2013) national policy on education which views education as an instrument par excellence for effecting national development. Thus for education to impact on an individual, it has to have quality.

Quality education according to Ejionueme and Oyoyo (2015), is defined as ameasure of the extent to which classroom instruction meets the set standards. In the same vein, Ayeni (2012) defined quality education as the measure of the extent to which the,training received from an institution enables the recipient to think clearly, independently and analytically to solve relevant societal problems in any given environment. This means that quality education encompasses quality learning resources inputs, instructional process, teachers' capacities development, effective management, monitoring and evaluation, and quality learning outcomes insecondary schools. The need to attain quality education has informed the calls byresearchers and scholars like Ogunnaike, Sholarin and Ezeugwa (2014), Bua andAda (2013) for the adoption of total quality management (TQM) in the nation's educational system especially in the secondary schools. This is because total quality management has been viewed by them as a systematic approach to school improvement.

TQM according to Burke (2010), is a set of practices that focus on continuous improvement, fulfilling the customers' needs, and lowering rework. It also stresses the increased involvement of employees and more teamwork, process redesign,competitive benchmarking, constant measurement of the outcomes, long-range thinking, team-based problem solving, and closer ties with the suppliers. In the educational sector, is a management model thatemphasizes leadership, teamwork, strategy, continuous improvement, communication, commitment, students' satisfaction, training on the job, empowerment and self-assessment. Two of the key principles of TQM are students' satisfaction and leadership principles. 
Students' satisfaction principle is the first among the fundamental principles is that the school must focus, first and foremost, on the students. In a TQM school, teacher-student teams arc the equivalent of the frontline workers in industry. Theproduct of their successful work together is the development of the students' capabilities, interests, and character. In one sense, the student is the recipient of educational services provided for the student's growth and improvement. Viewed in this way, the teacher and the school are suppliers of effective learning tools, environment, and systems to the student who is the school's primary customer (Ojo, 2008).

The second fundamental principle pertaining to total quality management isinstituting leadership. Pineda (2013) asserts that the primary task of leadership is to narrow the amount of changes within the system, thereby bringing everyone towards the goal of perfection. It can be argued that the more this changes isreduced the more likely it will be for the mission statement to be achieved. Itmeans bringing everyone towards the goal of effective learning for all.If leadership principles are properly adhered to by school administrators, it will lead to school improvement.

School improvement according to Hopkins (2008), as a distinct approach to educational change that aims to enhance student outcomes as well as strengthening the school's capacity for managing change. The purpose of school improvement is to impact ostensibly on the relationship between the teaching and learning process and the conditions that support it.According to (Freddy, 2008), the change which should take place as a result of the school improvement effort should not merely reflect an implementation of policies, but rather, improvements or adaptations of practice students satisfaction and leadership principles which transform the learning process to achieve the maximum impact on students, teachers and schools.However, this seem not to be the cases in secondary schools in Anambra State where secondary schools in the State are riddled by management inefficiencies which have resulted in poor quality standard. Duze (2012) observed that theenvisaged gaps and challenges of principals include ineffective management of the learning environment, lack of teamwork, poor communication method, poor management and lack of adequate funding. However, these views are however theoretical in nature and have not been empirically proven to be the case in the application of customer satisfaction and leadership principles in secondary schools in Anambra State.

\section{Statement of the Problem}

Secondary schools are meant to be hubs of learning where students are groomed and educated in preparation for life and higher education. Thus administrators and principals of secondary are expected to apply customer satisfaction and leadership principles that would help to facilitate the achievement of the goals of secondary education in Nigeria in general and Anambra State in particular. However, the achievement of these goals seem to be far-fetched. This is evident in the physical state of most secondary schools in Anambra State.

One gets worried as to the level of comfort ofthe students and staff in both the classroom setting and the entire environments looking at the dilapidated nature of the physical facilities in someof the secondary schools in the State. Some of the school buildings are moribund in terms of outlook, with broken floors, windows and leaking roofs. The environment of most secondary schools runs short of aesthetic view without proper beautification. Most often, the schools are overgrown with grasses which are dangerous for both staff and students because such may harbour snakes and dangerous animals, insects as well as pests. These situation calls for concern because one is inclined to ask if principals apply customer satisfaction and leadership principles for secondary school improvement in Anambra State?

\section{$>$ Purpose of the Study}

The main purpose of the study was to determine principals' application of students' satisfaction and leadership principles of total quality management for secondary school improvement in Anambra State. Specifically, the study determined:

- Principals' application of students' satisfaction principles of total quality management for secondary school improvement in Anambra State.

- Principals' application of leadership principles of total quality management for secondary school improvement in Anambra State.

\section{$>$ Research Questions}

The following research questions guided the study:

- To what extent do principals apply student satisfaction principle for secondary school improvement in Anambra State?

- To what extent do principals apply leadership principle for secondary school improvement in Anambra State?

\section{$>$ Hypotheses}

The following hypotheses were tested at 0.05 level of significance:

- There is no significant difference in the mean ratings of principals and teachers in secondary school on the extent principals apply student satisfaction principle for school improvement in Anambra State.

- There is no significant difference in the mean ratings of principals and teachers in secondary school on the extent principals apply leadership principle for school improvement in Anambra State. 


\section{METHOD}

The descriptive research design was adopted for the study. The study was carried out in Anambra State. The population of the study comprised 6664 principals and teachers (258 principals and 6406 teachers) from the 258 public secondary schools in the six education zones of the State. The sample of this study was 1999 respondents made up of 77 principals and 1922 teachers in secondary schools in Anambra State. The sample was $30 \%$ of the total population of 6664 principals and teachers in the State. Questionnaire was used as instrument for data collection. The instrument is titled, "Questionnaire on Extent of Principals' Application of Students Satisfaction and Leadership Principles for School Improvement (QEPASSLPSI)" and it has two main sections; A and B. Section A contains information on respondents' bio data relating to respondents position. Section B contains a total of 20 items arranged in two clusters of $\mathrm{B} 1$ and $\mathrm{B} 2$ in line with the two research questions guiding the study. The instrument was validated by three experts in the Faculty of Education,
Nnamdi Azikiwe University, Awka. The questionnaire reliability was ascertained through a pilot test. The data collected were analyzed with Cronbach Alpha and coefficient values of 0.75 and 0.77 were obtained for clusters Blto B2 respectively with an overall reliability co-efficient value of 0.76 for the whole instrument. The data collected from the respondents were analyzed using descriptive statistics such as arithmetic mean and standard deviation and inferential statistics specifically the t-test. The mean value was used to answer the research questions while the standard deviation was used to ascertain the homogeneity or otherwise of the respondents' responses and t-test was used to test hypotheses at 0.05 level of significance. For the hypotheses, where the calculated t-value was less than the critical value of $t$, it means that the variable did not significantly influence respondents' mean ratings and the hypothesis was not rejected. Conversely, where the calculated l-value was equal to or greater than the critical t-value, it means that the variable had a significant influence on the respondents' mean ratings and the hypothesis was rejected.

\section{RESULTS}

Research Question 1: To what extent do principals apply student satisfaction principle for secondary school improvement in Anambra State?

\begin{tabular}{|c|c|c|c|c|c|c|c|}
\hline \multirow[t]{2}{*}{ S/No. } & \multirow{2}{*}{$\begin{array}{c}\text { Items on students satisfaction principle } \\
\text { school improvement in your school: }\end{array}$} & \multicolumn{4}{|c|}{ Principals } & \multicolumn{2}{|c|}{ Teachers } \\
\hline & & & $\mathrm{N}=71$ & & & N-1545 & \\
\hline & & Mean & SD & Remarks & Mean & SD & Remarks \\
\hline \multirow[t]{4}{*}{1.} & Giving students opportunity to get guidance & 3.45 & 0.75 & Moderate & 3.50 & 0.97 & High \\
\hline & for their learning difficulties so as to improve & & & Extent & & & Extent \\
\hline & their academic performance for school & & & & & & \\
\hline & improvement. & & & & & & \\
\hline \multirow[t]{3}{*}{2.} & Ensuring that the temperatures in the study & 3.58 & 0.86 & High & 3.64 & 1.05 & High \\
\hline & premises are appropriate to enhance students & & & Extent & & & Extent? \\
\hline & learning for school improvement. & & & & & & \\
\hline \multirow[t]{2}{*}{3.} & Ensuring that students achieved objectives & 2.78 & 0.72 & Moderate & 3.08 & 0.78 & Moderate \\
\hline & set for their learning for school improvement. & & & Extent & & & Extent \\
\hline \multirow[t]{4}{*}{4} & (insuring that students have the opportunity & 2.45 & 0.68 & Low Extent & 2.89 & 0.74 & Moderate \\
\hline & to give teachers feedback on subjects to & & & & & & Extent \\
\hline & motivate them to learn for school & & & & & & \\
\hline & improvement. & & & & & & \\
\hline \multirow[t]{2}{*}{5.} & Ensuring that students are treated with & 3.50 & 0.87 & High & 2.16 & 0.61 & Low \\
\hline & respect for school improvement. & & & Extent & & & \\
\hline \multirow[t]{3}{*}{6.} & Making sure that there is no room for & 3.78 & 0.78 & High & 2.98 & 0.72 & Moderate \\
\hline & bullying amongst students and staff in the & & & Extent & & & Extent \\
\hline & school for school improvement.. & & & & & & \\
\hline \multirow[t]{4}{*}{7.} & Availing students' opportunity to use & 2.20 & 0.70 & Low Extent & 2.15 & 0.73 & Low \\
\hline & information and communication technologies & & & & & & \\
\hline & in the school to enhance their learning ability & & & & & & \\
\hline & for school improvement. & & & & & & \\
\hline \multirow[t]{2}{*}{8.} & Ensuring that the school's computers & 2.80 & 0.76 & Moderate & 2.87 & 0.83 & Moderate \\
\hline & function well for school improvement. & & & Extent & & & Extent \\
\hline \multirow[t]{2}{*}{9.} & Giving students sufficient feedback on their & 3.67 & 0.97 & High & 2.96 & 0.77 & Moderate \\
\hline & studies for school improvement. & & & Extent & & & Extent \\
\hline
\end{tabular}


ISSN No:-2456-2165

\begin{tabular}{|c|l|c|c|c|c|c|c|}
\hline 10. & Ensuring that the school has a guidance & 3.33 & 0.74 & Moderate & 3.10 & 0.70 & Moderate \\
\hline & counsellor to help assist student & & & Extent & & & Extent \\
\hline & psychologically for school improvement. & & & & & & \\
\hline & Cluster Total & $\mathbf{3 1 . 5 4}$ & $\mathbf{7 . 8 3}$ & & $\mathbf{2 9 . 3 3}$ & $\mathbf{6 . 9 3}$ & \\
\hline & Cluster Mean & $\mathbf{3 . 1 5}$ & $\mathbf{0 . 7 8}$ & Moderate & $\mathbf{2 . 9 3}$ & $\mathbf{0 . 6 9}$ & Moderate \\
\hline & & & Extent & & & Extent \\
\hline
\end{tabular}

Table 1:- Respondents mean ratings on the extent of principals' application of student satisfaction principle for secondary school improvement in Anambra State

Data in Table 1 reveal that the principals rated four items, 2, 5, 6 and 9 to a high extent with mean ratings of $3.58,3.50,3.78$ and 3.67 and standard deviations ranging from 0.78 to 0.97 while teachers rated items 1 and 2 to a high extent with mean ratings of 3.50 and 3.67 and standard deviations of 0.97 and 1.05 respectively. The principals also rated four items, 1, 3, 8 and 10 to a moderate extent with mean ratings ranging from 2.78 to 3.45 and standard deviations ranging from 0.72 to 0.76 , while teachers rated six items, $3,4,6,8,9$ and 10 with mean ratings ranging from 0.70 to 0.78 . Furthermore, the principals rated items 4 and 7 to a low extent with mean ratings of 2.45 and 2.20 and standard deviations of 0.68 and 0.70 respectively while teachers rated items 5 and 7 to a low extent with mean ratings of 2.16 and
2.15 and standard deviation of 0.61 and 0.73 respectively. The cluster mean of 3.15 for principals and 2.93 for teachers indicates that principals in public secondary schools in Anambra State apply student satisfaction principle for school improvement to a moderate extent. The standard deviation shows that the responses of principals and teachers rating for each item is slim, suggesting that their responses still clustered, though there is difference in the cluster scores of 0.78 and 0.69 respectively.

Research Question 2: To what extent do principals apply leadership principle for secondary school improvement in Anambra State?

\begin{tabular}{|c|c|c|c|c|c|c|c|}
\hline \multirow[t]{3}{*}{ S/No. } & Items on leadership principle for & \multicolumn{4}{|c|}{ Principals } & \multicolumn{2}{|c|}{ Teachers } \\
\hline & \multirow[t]{2}{*}{ school improvement in your school: } & & $\mathrm{N}=71$ & \multicolumn{4}{|c|}{$\mathrm{N}=1545$} \\
\hline & & Mean & SD & Remarks & Mean & SD & Remarks \\
\hline \multirow[t]{3}{*}{11,} & Treating teachers as individuals rather & 3.67 & 0.84 & High & 2.37 & 0.73 & Low Extent \\
\hline & than just as members of a group so as to & & & Extent & & & \\
\hline & motivate to work for school- improvement. & & & & & & \\
\hline \multirow[t]{4}{*}{12.} & Regularly holding meetings with teachers & 2.47 & $0.7 \mathrm{~S}$ & Low & 2.10 & 0.69 & Low Extent \\
\hline & to discuss issues arising to increase their & & & Extent & & & \\
\hline & sense of belonging for school & & & & & & \\
\hline & improvement. & & & & & & \\
\hline \multirow[t]{3}{*}{13.} & Delegating responsibilities to staff to & 2.59 & .0 .72 & Moderate & 2,22 & 0.75 & Low Extent \\
\hline & motivate them to work for school & & & Extent & & & \\
\hline & improvement. & & & & & & \\
\hline \multirow[t]{3}{*}{14.} & Displaying a sense of power and & 3.82 & 0.98 & High & 2.98 & 0.70 & Moderate \\
\hline & confidence in carrying- out duties for & & & Extent & & & Extent \\
\hline & school improvement. & & & & & & \\
\hline \multirow[t]{3}{*}{15.} & Discussing very clearly teachers & 3.61 & 0.67 & High & 2.75 & $0.8 !$ & Moderate \\
\hline & responsibility for achieving performance & & & Extent & & & Extent \\
\hline & objectives for school improvement. & & & & & & \\
\hline \multirow[t]{3}{*}{16.} & Making clear rewards that will be & 2.40 & 0.59 & Low & 3.12 & 0.72 & Moderate \\
\hline & received when work is successfully & & & Extent & & & Extent \\
\hline & accomplished for school improvement. & & & & & & \\
\hline \multirow[t]{2}{*}{17.} & Expressing satisfaction when teachers do & 3.50 & 0.70 & High & 2.80 & 0.77 & Moderate \\
\hline & their work well for school improvement. & & & Extent & & & Extent \\
\hline \multirow[t]{3}{*}{ 18: } & Regularly supervising teachers classroom & 2.20 & 0.67 & Low & 3.10 & 0.84 & Moderate \\
\hline & instructional capabilities for school & & & Extent & & & Extent \\
\hline & improvement. & & & & & & \\
\hline
\end{tabular}


ISSN No:-2456-2165

\begin{tabular}{|c|c|c|c|c|c|c|c|}
\hline 19. & Giving teachers feedback on their & 3.59 & 0.78 & High & 3.00 & 0.78 & Moderate \\
\hline & instructional capabilities for school & & & Extent & & & Extent \\
\hline improvement. & & & & & & \\
\hline 20. & Encouraging critical thinking and & 3.45 & 0.74 & Moderate & 3.65 & 1.03 & High \\
\hline & problem solving among staff to make the & & & Extent & & & Extent \\
\hline & school better for school improvement. & & & & & & \\
\hline & Cluster Total & $\mathbf{3 1 . 3}$ & $\mathbf{7 . 5}$ & & $\mathbf{2 8 . 1}$ & $\mathbf{7 . 8}$ & \\
\hline & Cluster Mean & $\mathbf{3 . 1 3}$ & $\mathbf{0 . 7 5}$ & Moderate & $\mathbf{2 . 8 1}$ & $\mathbf{0 . 7 8}$ & Moderate \\
\hline
\end{tabular}

Table 2:- Respondents mean ratings on the extent of principals' application of leadership principle for secondary school improvement in Anambra State

Data in Table 2 reveal that the principals rated five items, $11,14,15,17$ and 19 to a high extent with mean ratings ranging from 3.50 to 3.82 and standard deviations ranging from 0.67 to 0.84 while teachers rated item 20 to a high extent with mean ratings of 3.65 and standard deviation of 1.03 . The principals also rated two items, 13 and 20 to a moderate extent with mean ratings of 2.59 and 3.45 and standard deviations ranging of 0.72 and 0.74 , while teachers rated six items, 14, 15, 16, 17, 18 and 19 with mean ratings ranging from 0.70 to 0.84 . Furthermore, the principals rated items 12,16 and 18 to a low extent with mean ratings of $2.47,2.40$ and 2.20 and standard deviations of $0.78,0.59$ and 0.67 respectively while teachers rated items 11,12 and 13 to a low extent with mean ratings of $2.37,2.10$ and 2.22 and standard deviation of $0.73,0.69$ and 0.75 respectively. The cluster mean of 3.13 for principals and 2.81 for teachers indicates that principals in public secondary schools in Anambra state apply leadership principle for school improvement to a moderate extent. The standard deviation shows that the responses of principals and teachers rating for each item is slim, suggesting that their responses still clustered, though there is difference in the cluster scores of 0.75 and 0.78 respectively.

Hypothesis 1: There is no significant difference in the mean ratings of principals and teachers in secondary schools on the extent principals' apply student satisfaction principle for school improvement in Anambra State.

\begin{tabular}{|c|c|cccccc|}
\hline Status & N & XSD & df & Cal. t & t-value & \multicolumn{2}{c|}{ Decision } \\
\hline Principals & 71 & 3.15 & 0.78 & 1614 & 1.62 & 1.96 & NS \\
\hline Teachers & 1545 & 2.93 & 0.69 & & & & \\
\hline Total & 1616 & \multicolumn{7}{|c|}{0} & & & & & \\
\hline
\end{tabular}

Table 3:- t-test Analysis of the mean ratings of principals and teachers in secondary schools on the extent principals' apply student satisfaction principle for school improvement in Anambra State

Result in Table 3 show that principals' (71 in number) had a mean rating of 3.15 and standard deviation of 0.78 , while the teachers (1872 in number) had a mean rating of 2.93 and standard deviation of 0.69 . These yielded a calculated t-value of 1.62 at 1614 degree of freedom. Since the calculated t-value of 1.62 is greater than the critical t-value of 1.96, the null hypothesis is accepted. Hence, there is no significant difference in the mean ratings of principals and teachers in secondary school on the extent-principals' apply student satisfaction principle forschool improvement in Anambra State.

> Hypothesis 2: There is no significant difference in the mean ratings of principals and teachers in secondary schools on the extent principals' apply leadership principle for school improvement in Anambra State.

\begin{tabular}{|lccccccc|}
\hline Status & N & $\boldsymbol{X}$ & SD & df & Cal. t & t-value & Decision \\
\hline Principals & 71 & 3.13 & 0.82 & 1614 & 0.90 & 1.96 & NS \\
Teachers & 1545 & 2.81 & 0.75 & & & & \\
Total & 1616 & & & & & & \\
\hline
\end{tabular}

Table 4:- t-test Analysis of the mean ratings of principals and teachers in secondary schools on the extent principals' apply leadership principle for school improvement in Anambra State 
Result in Table 4 show that principals (71 in number) had a mean rating of 3.13 and standard deviation of 0.82 , while the teachers (1803 in number) had a mean rating of 2.81 and standard deviation of 0.75 . These yielded a calculated t-value of 0.90 at 1614 degree of freedom. Since the calculated t-value of 0.90 is greater than the critical t-value of 1.96 . Hence, there is no significant difference in the mean ratings of principals and teachers in secondary schools on the extent principals apply leadership principle for school improvement in Anambra State.

\section{DISCUSSION}

Findings on the first research question indicated that public secondaryschool principals in Anambra State apply student satisfaction principle to a moderate extent. This might be as a result of the inability on the part of some principals to interact with students to determine their needs in some schools. In some schools it appears that the students are afraid of the principals. This impedes their ability to discuss their needs. Furthermore, the finding is in agreement with the findings of Afzal and Afzal (2015) who reported that student satisfaction is not adequate enough in schools. Afzal and Afzal (2015) opined that not giving high priority to student satisfaction would result in reduced performance in the school. This assertion is in agreement with the finding Naveed, Shahab and Muhammad (2013) who discovered that there is a positive relationship between student satisfaction and student motivation to learning. Hence, this calls for the application of student satisfaction principles in schools to attain school objectives and goals. Furthermore, findings of the study revealed that principals and teachers did not significantly differ in their mean ratings on the extent of principals' application of student satisfaction principle for school improvement. This shows that principals and teachers are in agreement on the extent of application of student satisfaction principle for school improvement. This is in disagreement with the findings of Oyoyo (2014) who noted that principals and teachers significantly differed in their opinion on principals' application of student satisfaction principle in their schools. This implies that principals and teachers of public secondary schools in Anambra State irrespective of status opined that principals apply student satisfaction principle to a moderate extent.

Findings on the second research question indicated that public secondary school principals in Anambra State apply leadership principle to a moderate extent-This finding in the researcher's view may have resulted because of some principals' inability to carry their teachers along. Some of the principals appear to be more authoritarian in nature and do not seem to indulge other members of theschool staff in the administrative processes of the school. This finding is in agreement with the findings of Maduabuike (2011) who revealed that school principals apply distributed leadership role to a moderate extent. Maduabuike also revealed that the barriers to distributed leadership arc: constant directives from the government, continuous reliance on government policies, constant changes on educational policies, principal's insufficient skills in management, and lack of timeto implement new policies on education. Similarly, Kiboss and Jemiryott (2014) reported a positive correlation between principals' leadership styles identified and school improvement. It means that whenever the principal employed a leadership style, there is bound to be a direct response in relation to school improvement which was cither low or high amongst the teachers. Kiboss and Jemiryott also revealed that those teachers whose principals practiced autocratic leadership style tend to get dissatisfied and show less commitment to duty, than a more democratic kind of leadership style elicits a higher job satisfaction index and consequently a stronger commitment to duty, that transactional leadership style does not improve or lower the teachers job satisfaction, which is an indication that transactional style of leadership is least effective in changing the school improvement because it tends to assume that people are largely motivated by simple rewards, such as management of punishments and rewards. Furthermore, findings of the study revealed that principals and teachers did not significantly differ in their mean ratings on the extent of principals' application of leadership principle for. School improvement. This implies that principals and teachers of public secondary schools in Anambra State irrespective of status opined that principals apply leadership principle to a moderate extent.

\section{CONCLUSION}

The researcher concludes that principals applied student satisfaction and leadership principles to a moderate extent. This is because principals do not ensure that students have opportunity to give teachers feedback on subjects, they also do not ensure that students are treated with respect and they do not regularly hold meetings with teachers to discuss issues arising to increase their sense of belonging among others. It therefore becomes imperative that measures are put in place to improve the application of customer satisfaction and leadership principles for school improvement in Anambra State.

\section{RECOMMENDATIONS}

Based on the findings of the study, the researchers make the following recommendations:

$>$ The Post Primary School Service Commission in Conjunction with the Ministry of education should organize in-service training programmes that will educate principals on the current trends in improving students' satisfaction in secondary schools.

$>$ The Post Primary School Service Commission in conjunction with the Ministry of education should organise school leadership symposium or seminars that will expose the school principals to leadership principles and methods that they can apply in the management of their schools. 
The State government should ensure the provision of adequate physical facilities like classrooms, chairs, tables, white boards and fans for teaching and learning in secondary schools.

Principals are also advised to ensure that teachers are actively involved in the decision making processes of the school. This will go a long way in motivating teachers to put in their best and it will ultimately lead to school improvement.

Principals should delegate responsibilities more to teachers as that will give them a feeling of belonging and increase their work commitment.

\section{REFERENCES}

[1]. Afzal, M. T. \& Afzal, M. (2015). Comparison of students' satisfaction and achievement at secondary level in Islamabad. American Journal of Educational Research, 3 (12), 1524-1527.

[2]. Bua, F. T. \& Ada, J. N. (2013). Impact of total quality management (TQM) on secondary school education for national transformation: The case of Benue NorthWest Senatorial District of Benue State, Nigeria. Journal of Education and Practice, 4 (20), 68-75.

[3]. Burke, W. W. (2010). Organization change: Theory and practice (3rd ed.). Sage Publications, Inc.

[4]. Duze, C. (2012). Comparative analysis of principals' management strategies in public and private secondary schools in Anambra State of Nigeria. International Journal of Arts and Humanities, 1 (1), 239-256.

[5]. Ejionueme, L. K. \&Oyoyo, A. O. (2015). Application of total quality management (TQM) in secondary school administration in Umuahia Education Zone. Journal of Education and Practice, 6 (27), 102- 111.

[6]. Federal Republic of Nigeria (2013). National policy on education ( $6^{\text {th }}$ ed.). Eagos: NERDC

[7]. Freddy, J. (2008). An exploration of school improvement theory and practice in secondary schools in Trinidad and Tobago. Paper presented at the British Educational Research Association Annual Conference, Heriot-Watt University, Edinburgh, 3-6 September.

[8]. Hopkins, D. (2008). School improvement for real. London: RoutledgeFalmer.

[9]. Kiboss, J. K. \&Jemiryott, Ii. K. S. (2014). Relationship between principals'leadership styles and secondary school teachers'job satisfaction in Nandi South District, Kenya. Journal of Education and Human Development, 3 (2), 493-509.

[10]. Madubuike, C. A. (2011). Distributed leadership style and management of public secondary schools in Umahia North Central Education Zone (Unpublished Master's Thesis, Department of Educational Foundations, University of Nigeria Nsukka).
[11]. Naveed, H., Shahab, A. M. \& Muhammad, M. K. (2013). Measuring relationshipbetween students' satisfaction and motivation in secondary schools of Pakistan. Middle-East Journal of Scientific Research, 18 (9), 1231-1239.

[12]. Ogunnaike, O. O., Sholarin, A. \&Ezeugwa, I. C. (2014). An empirical analysis of total quality management and perceived corporate image in higher education management. European Scientific Journal, 1 (22), 236-250.

[13]. Ojo, B. J. (2008). Total quality management. Culture and Productivityimprovement in Ethiopia Higher institutions. Online Journal of academic leadership, 6(3). Retrieved from $h t t p: / / w w w$. academicleadership. org/emprical_ research/459, html.

[14]. Oyoyo, A. O. (2014). Appraisal of the application of total quality management in secondary school administration in Umuahia Education Zone (Master's thesis, Department of Educational Foundations University of Nigeria, Nsukka).

[15]. Pineda, A. P. M. (2013). Total quality management in educational institutions: Influences on customer satisfaction. Asian Journal of Management Sciences and Education, 2 (3), 31-46. 